\title{
The Historical Trend of Air Pollution and Its Impact on Human Health in Campania Region (Italy)
}

\author{
Domenico Toscano * and Fabio Murena \\ Chemical, Materials and Production Engineering Department-University of Naples "Federico II", \\ 80125 Naples, Italy; murena@unina.it \\ * Correspondence: domenico.toscano@unina.it
}

Citation: Toscano, D.; Murena, F. The Historical Trend of Air Pollution and Its Impact on Human Health in Campania Region (Italy). Atmosphere 2021, 12, 553.

https://doi.org/10.3390/atmos12050553

\section{Academic Editors:}

Francesca Costabile, Tareq Hussein and Lorenzo Massimi

Received: 1 April 2021

Accepted: 22 April 2021

Published: 25 April 2021

Publisher's Note: MDPI stays neutral with regard to jurisdictional claims in published maps and institutional affiliations.

Copyright: (c) 2021 by the authors. Licensee MDPI, Basel, Switzerland. This article is an open access article distributed under the terms and conditions of the Creative Commons Attribution (CC BY) license (https:/ / creativecommons.org/licenses/by/ $4.0 /)$.

\begin{abstract}
The Campania region covers an area of about $13,590 \mathrm{~km}^{2}$ with 5.8 million residents. The area suffers from several environmental issues due to urbanization, the presence of industries, wastewater treatment, and solid waste management concerns. Air pollution is one of the most relevant environmental troubles in the Campania region, frequently exceeding the limit values established by European directives. In this paper, airborne pollutant concentration data measured by the regional air quality network from 2003 to 2019 are collected to individuate the historical trends of nitrogen dioxide $\left(\mathrm{NO}_{2}\right)$, coarse and fine particulate matter with aerodynamic diameters smaller than $10 \mu \mathrm{m}$ (PM10) and $2.5 \mu \mathrm{m}$ (PM2.5), and ozone $\left(\mathrm{O}_{3}\right)$ through the analysis of the number of exceedances of limit values per year and the annual average concentration. Information on spatial variability and the effect of the receptor category is obtained by lumping together data belonging to the same province or category. To obtain information on the general air quality rather than on single pollutants, the European Air Quality Index (EU-AQI) is also evaluated. A special focus is dedicated to the effect of deep street canyons on air quality, since they are very common in the urban areas in Campania. Finally, the impact of air pollution from 2003 to 2019 on human health is also analyzed using the software AIRQ+.
\end{abstract}

Keywords: air pollution; historical trend; AQI; AIRQ+; Campania; Mediterranean area

\section{Introduction}

Air pollution is the major environmental risk in Europe [1-3] and one of the most critical in the world. In fact, the World Health Organization (WHO) estimates that air pollution, both environmental and domestic, causes 7 million deaths per year, 5.6 million deaths from non-communicable diseases, 1.5 million from pneumonia, and 3\% from cardiorespiratory mortality. It is also estimated that $90 \%$ of premature deaths per year due to air pollution are concentrated in middle- and low-income countries.

The effects of air pollution on human health can be chronic (long-term) or acute (short-term). Chronic effects occur after prolonged exposure and include cardiovascular and pulmonary diseases, respiratory diseases, chronic changes in physiological functions, lung cancer, chronic cardiovascular diseases, and intrauterine growth restrictions. Acute effects due to short-term exposure (hours or days) to high concentrations of pollutants include respiratory and cardiovascular problems and physiological changes. Furthermore, climate change resulting from environmental pollution can also influence the geographic distribution of many infectious diseases [4-7]. Regarding age, epidemiological investigations of the effects of air pollution on health show that children and the elderly are the two groups most likely to be affected due to their relatively weak immune systems [8]. Maternal exposure to ambient air pollution is associated with adverse impacts on fertility, pregnancy, newborns, and children $[9,10]$.

There is also emerging evidence that exposure to air pollution is associated with diabetes in adults and may be linked to obesity, systemic inflammation, Alzheimer's disease, and dementia [11,12]. 
Italy ranks first in Europe for premature deaths attributable to particulate matter with aerodynamic diameters smaller than $2.5 \mu \mathrm{m}$ (PM2.5), ozone $\left(\mathrm{O}_{3}\right)$, and nitrogen dioxide $\left(\mathrm{NO}_{2}\right)$ levels, with 91,050 cases in 2013 [13]. A team of researchers from the Royal Netherlands Meteorological Institute, using data from the ozone monitoring tool on NASA's Aura satellite, revealed that Northern Italy is one of the most polluted areas in Europe in terms of smog and air pollution due in part to climatic and geographical conditions which cause the stagnation of pollutants [14].

The VIIAS Project (Integrated Assessment of the Impact of Air Pollution on the Environment and on Health, www.viias.it) carried out the health-impact assessment (HIA) of $\mathrm{NO}_{2}$ and PM2.5 by using Italian national model scenarios for 2020 and a 2005 baseline situation [15]. The authors used the Atmospheric Modelling System of the Italian National Integrated Assessment Model (AMS-MINNI dispersion model) and population-weighted exposure by region in order to provide a more precise estimate of the number of deaths attributable to air pollution in Italy. The results suggested 19,945 deaths from cardiovascular diseases, 3197 deaths from respiratory diseases, and 2938 from lung cancer.

To quantify and communicate the air quality through a single numeric value, several indexes have been developed [16,17]. The Pollution Standards Index (PSI) was initially established [18]. The PSI was subsequently revised and implemented by the United States Environmental Protection Agency (USEPA) in 1999 and became known as the EPA-Air Quality Index (EPA-AQI) [19]. The EPA-AQI is a daily index based on the concentration values of five key pollutants, including particulate matter with aerodynamic diameters smaller than $10 \mu \mathrm{m}$ (PM10), PM2.5, $\mathrm{O}_{3}$, sulfur dioxide $\left(\mathrm{SO}_{2}\right)$, and $\mathrm{NO}_{2}$. The EPA-AQI assumes numerical values from 1 to 6 corresponding with six air quality categories-good, moderate, unhealthy for sensitive groups, unhealthy, very unhealthy, and hazardous, associated with different colors (green, yellow, orange, red, purple, and maroon). Recently, the European community has developed a European air quality index (EU-AQI) (https: / / airindex.eea.europa.eu/Map/AQI/Viewer/).

The EU-AQI assumes numerical values from 1 to 5 corresponding with five air quality categories-very good, good, medium, poor, and very poor. In order to calculate the EU-AQI, a daily sub-index is calculated for each pollutant via linear interpolation of the measured pollutant concentrations between the concentration levels. Then, the daily EU-AQI is assumed as the maximum of the sub-indices calculated.

The assessment of the impact of air pollution on human health has been performed by many studies [20-27]. To measure health outcomes due to air pollution exposure, the WHO developed the AIRQ+ model. This model has been widely applied [28-30].

This program is used to estimate the impact of exposure to specific atmospheric pollutants on the health of people living in a certain period and area. The assessment is based on the attributable proportion (AP), defined as the fraction of the health outcomes in a certain population attributable to exposure to a given atmospheric pollutant, assuming a relationship between exposure and health outcomes.

The control of air quality in Campania is under the responsibility of the regional environmental agency (ARPAC), which manages the air quality monitoring network made up of several fixed stations distributed across the entire territory.

These data are mainly used to verify the observance of the limit values established by European legislation. At present, they have not yet been used to analyze long historical trends or to assess the impact of air pollution on human health in the Campania region.

This work is structured in two parts:

1. Analysis of the historical trend of atmospheric pollution in Campania (2003-2019).

2. Analysis of the impact of pollution on mortality and morbidity.

In the first part, data from fixed air quality stations are analyzed to highlight the temporal trends of single pollutants $\left(\mathrm{NO}_{2}, \mathrm{PM} 10, \mathrm{PM} 2.5\right.$, and $\left.\mathrm{O}_{3}\right)$ and of the European air quality index (AQI). 
In the second part, the impact of air pollution on human health in Campania is assessed using the AIRQ+ software, which estimates related mortality or morbidity in percentages.

The results of this work can be used as a support to better define intervention strategies and policies aimed at improving air quality and reducing the impact on public health in Campania.

\section{Materials and Methods}

\subsection{The Area Studied}

The Campania region covers an area of about $13,590 \mathrm{~km}^{2}$. From an administrative point of view, it is divided into five provinces. It is located in the south of Italy at the center of the Mediterranean Sea and is surrounded by the Apennine to the east, which occupies a big portion of the territory, and the Tyrrhenian Sea to the west. Its central position in the Mediterranean area is rooted in history.

According to Koppen [31], the Campania region has a Mediterranean climate with a cold winter and dry summer, with wetter summers near the coastline and more severe winters in the mountains [32]. The differences in climate between the high mountains in the interior and the coastal areas are quite large. Campania is the cradle of the "Mediterranean diet" similar to the eating habits of Spain and Greece, including high consumption of olive oil, legumes, cereals, fruits, and vegetables. Additionally, the urbanization of most of the cities in Campania is similar to other cities on the coasts of the Mediterranean Sea, characterized by a high density of buildings and very narrow streets.

Now, about 5.8 million people live in Campania. Of them, 4 million live in the metropolitan area of Naples, and about 1 million are residents in the city of Naples, the capital of Campania.

The main anthropogenic sources contributing to emissions of airborne pollutants in Campania are, for nitrogen oxides (NOx), "road transport" with $57.70 \%$, "maritime transport" with $18.43 \%$, and "non-industrial combustion plants" with 7.62\%. For PM10 and PM2.5, the major contribution in terms of emissions is "non-industrial combustion plants" with $63.05 \%$ and $67.64 \%$ for PM10 and PM2.5, respectively, followed by "other sources and sinks" with $14.45 \%$ (PM10) and 12.83\% (PM2.5) and "road transport" with 11.36\% for PM10 and 10.11\% for PM2.5 (http:/ / www.sinanet.isprambiente.it/it/sia-ispra/ inventaria/disaggregazione-dellinventario-nazionale-2015/view).

Campania has the highest age-standardized death rate in Italy, equal to about 45 deaths per 10,000 inhabitants (a national average of about 33 deaths per 10,000 inhabitants) due to cardiovascular disease. Additionally, with regard to respiratory diseases, pneumonia, bronchitis, asthma, and chronic obstructive pulmonary disease (COPD), Campania is the leading region in Italy for deaths from chronic diseases of the lower respiratory tract with a mortality rate of 4.2 per 10,000 inhabitants. As for tumors, in Campania, the average survival rate for all tumors diagnosed in 2005-2009 is one of the worst in Italy, being less than $55 \%$.

\subsection{Air Pollution Data (Monitoring Network)}

Data on air quality used in this paper are measured at fixed monitoring stations managed by Campania Regional Environmental Protection Agency (ARPAC). The air quality network was realized in the 1990s. Our analysis ranges from 2003 to 2019. In this period, the structure of the regional air quality network changed. In 2003, the number of fixed stations was 19 with 77 analyzers. Pollutants monitored were carbon monoxide (CO), $\mathrm{NO}_{2}, \mathrm{NOx}, \mathrm{O}_{3}, \mathrm{PM} 10$, total suspended particles (TSP), and $\mathrm{SO}_{2}$. The configuration of the fixed-station network was improved in 2019, increasing the number of monitoring stations located with great density in sensitive areas in order to obtain optimal spatial coverage of the area. At present, the number of stations is 42, and the number of analyzers is 196 . Table 1 reports a list of the fixed monitoring stations with the indication of the province and category. On the basis of previous studies [33,34], three different station categories 
are considered: traffic, industrial, and background. Traffic stations are located in urban or suburban areas near high-traffic roads; background stations are in urban or suburban areas far from emission sources; industrial stations are in industrial areas. Only two stations are sited in rural areas (San Gregorio Lago Matese and Ottati Alburni) and are considered background stations.

Table 1. A list of air quality monitoring stations in Campania in 2019.

\begin{tabular}{|c|c|c|c|c|}
\hline Official Name & Province & Category & UTM Easting [m] & UTM Northing [m] \\
\hline CE51 Istituto Manzoni & Caserta & Background & $444,422.38$ & $4,547,702.99$ \\
\hline CE52 Scuola de Amicis & Caserta & Traffic & $443,818.09$ & $4,547,512.98$ \\
\hline CE54 Scuola Settembrini & Caserta & Traffic & $447,731.83$ & $4,544,040.48$ \\
\hline Aversa Scuola Cirillo & Caserta & Traffic & $433,653.01$ & $4,536,336.30$ \\
\hline San Felice a Cancello Centro scolastico & Caserta & Traffic & $451,550.08$ & $4,537,856.89$ \\
\hline NA01 Osservatorio Astronomico & Naples & Background & $437,174.00$ & $4,523,893.00$ \\
\hline NA02 Ospedale santobono & Naples & Traffic & $435,187.00$ & $4,522,320.00$ \\
\hline NA06 Museo Nazionale & Naples & Traffic & $436,897.00$ & $4,522,837.00$ \\
\hline NA07 Ferrovia & Naples & Traffic & $438,617.00$ & $4,522,822.00$ \\
\hline NA08 Ospedale Nuovo Pellegrini & Naples & Traffic & $438,947.00$ & $4,524,837.00$ \\
\hline NA09 Via Argine & Naples & Traffic & $444,493.00$ & $4,523,854.00$ \\
\hline Parco Virgiliano & Naples & Background & $430,800.00$ & $4,516,727.00$ \\
\hline Via Epomeo & Naples & Background-Industrial & $433,038.00$ & $4,521,846.00$ \\
\hline Pozzuoli Villa Avellino & Naples & Background & $426,005.00$ & $4,519,470.00$ \\
\hline Casoria Scuola Palizzi & Naples & Background & $440,934.00$ & $4,529,517.00$ \\
\hline Pomigliano d'Arco Area ASI & Naples & Industrial & $448,210.00$ & $4,530,151.00$ \\
\hline Volla Via Filichito & Naples & Background-Industrial & $445,239.00$ & $4,526,346.00$ \\
\hline Acerra Zona Industriale & Naples & Industrial & $449,608.00$ & $4,536,666.00$ \\
\hline Acerra Scuola Caporale & Naples & Traffic & $446,984.00$ & $4,532,338.00$ \\
\hline Portici Parco Reggia & Naples & Background & $445,121.00$ & $4,518,521.00$ \\
\hline Torre Annunziata Scuola Pascoli & Naples & Background & $452,575.00$ & $4,512,327.00$ \\
\hline San Vitaliano Scuola Marconi & Naples & Background & $456,334.00$ & $4,530,486.00$ \\
\hline Teverola via San Lorenzo & Caserta & Industrial & $432,940.32$ & $4,538,057.47$ \\
\hline Marcianise Regi Lagni & Caserta & Background-Industrial & $440,050.00$ & $4,538,408.00$ \\
\hline Avellino AV41 Scuola V Circolo & Avellino & Background & $482,044.00$ & $4,530,239.05$ \\
\hline Avellino Scuola Alighieri & Avellino & Traffic & $481,934.20$ & $4,529,758.65$ \\
\hline Nocera Inferiore Scuola Solimena & Salerno & Traffic & $469,896.76$ & $4,509,985.79$ \\
\hline Benevento Zona Industriale & Benevento & Industrial & $486,249.26$ & $4,555,075.28$ \\
\hline Benevento BN32 Via Mustilli & Benevento & Traffic & $482,322.44$ & $4,553,370.69$ \\
\hline Benevento Campo Sportivo & Benevento & Background & $481,525.00$ & $4,551,619.88$ \\
\hline Battipaglia Parco Fiume & Salerno & Background & $497,956.46$ & $4,495,583.88$ \\
\hline Polla Area Tritovagliatore & Salerno & Industrial & $544,747.85$ & $4,481,935.50$ \\
\hline Cava dei Tirreni Stadio & Salerno & Background & $474,866.50$ & $4,506,718.58$ \\
\hline Salerno SA22 Osp.Via Vernieri & Salerno & Traffic & $480,250.95$ & $4,503,507.03$ \\
\hline Salerno SA23 Scuola Conti & Salerno & Background & $481,203.37$ & $4,504,962.8$ \\
\hline Salerno Parco Mercatello & Salerno & Background & $483,474.72$ & $4,501,191.50$ \\
\hline Solofra Zona Industriale & Avellino & Industrial & $485,219.30$ & $4,520,509.05$ \\
\hline Sparanise Ferrovia & Caserta & Industrial & $423,862.98$ & $4,559,716.01$ \\
\hline Pignataro M. Area Industriale & Caserta & Background-Industrial & $428,762.98$ & $4,557,808.96$ \\
\hline San Gregorio Matese Lago & Caserta & Background & $450,830.15$ & $4,585,238.14$ \\
\hline Ottati Alburni & Salerno & Background & $525,323.02$ & $4,480,033.75$ \\
\hline Ariano Irpino Stadio & Avellino & Background & $508,112.06$ & $4,556,086.83$ \\
\hline
\end{tabular}

The pollutants monitored are $\mathrm{CO}, \mathrm{NO}_{2}, \mathrm{O}_{3}$, particulate matter (PM10 and PM2.5), $\mathrm{SO}_{2}$, and benzene. The pollutants measured in each station are not the same and depend mainly on the station category.

The criteria used for the localization of the stations, the measurement methods, and the quality standards align with European directives [35].

The spatial distribution of the monitoring stations in the region is reported in Figure 1. 


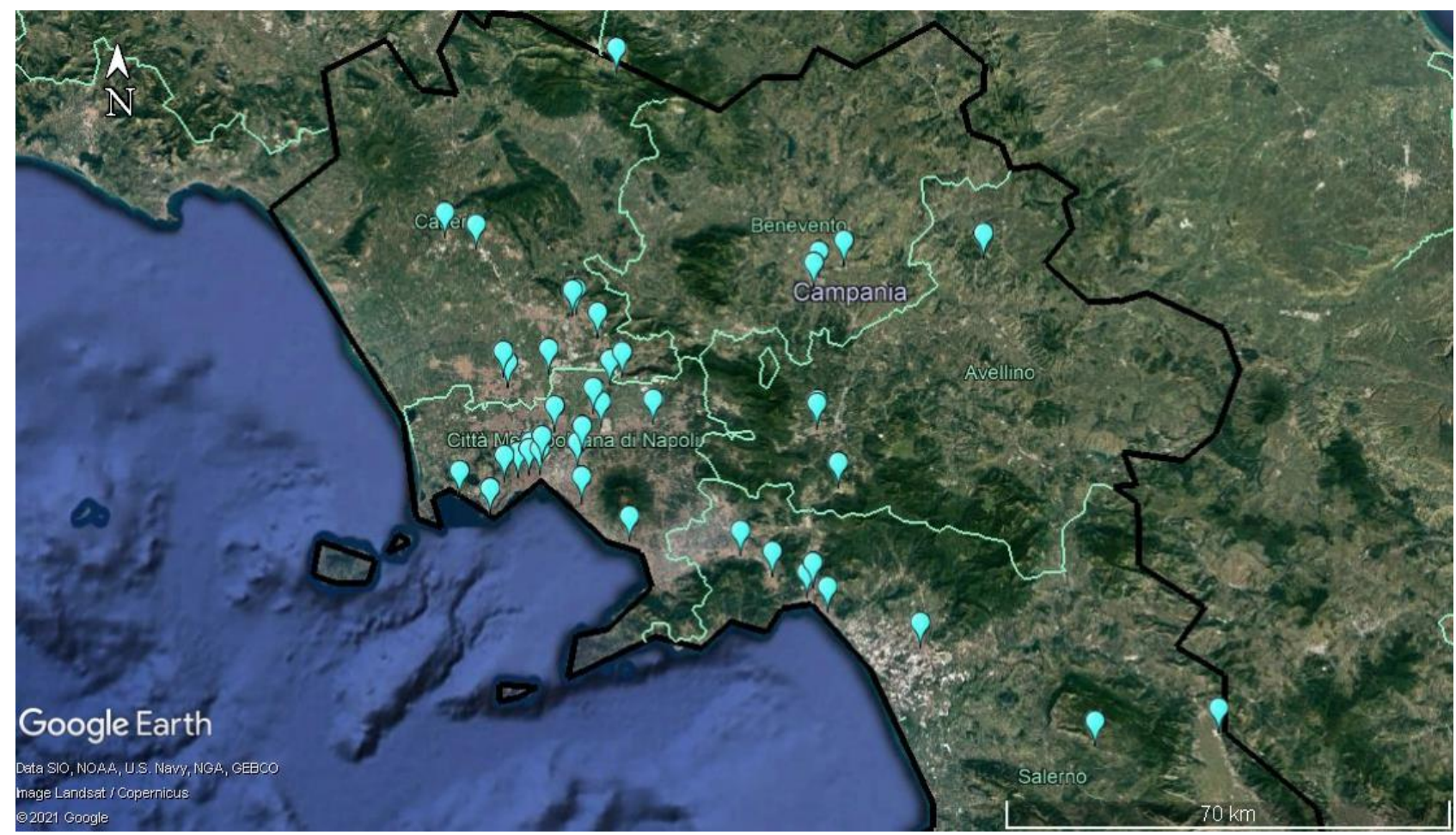

Figure 1. A map of air quality monitoring stations in Campania in 2019.

Before analyzing air quality data, the monitoring efficiency per solar-year of each analyzer was verified. The solar-year efficiency was measured based on 1-h or 1-day time-average data as:

$$
E 1_{i, r, y}=\frac{\text { number of valid } 1 \text { hour av.data }}{\text { total number of hours in the year }}
$$

for $\mathrm{NO}_{2}$ and $\mathrm{O}_{3}$, and

$$
E 24_{i, r, y}=\frac{\text { number of valid } 24 \text { hours av. data }}{\text { total number of days in the year }}
$$

for PM10 and PM2.5. The subscripts $i, r$, and $y$ refer to the pollutant, the receptor, and the year, respectively.

In some years, the monitoring efficiency was very low with large data gaps. Figure 2 shows the $\%$ of valid data depending on the fixed efficiency criteria. Imposing a highefficiency minimum criterion $(>75 \%$ ) would determine the loss of $35-45 \%$ of data, depending on the specific pollutant. For this reason, the efficiency criteria are fixed at $50 \%$. Yearly datasets not respecting the fixed minimum efficiency criteria were not considered in the successive analysis. 


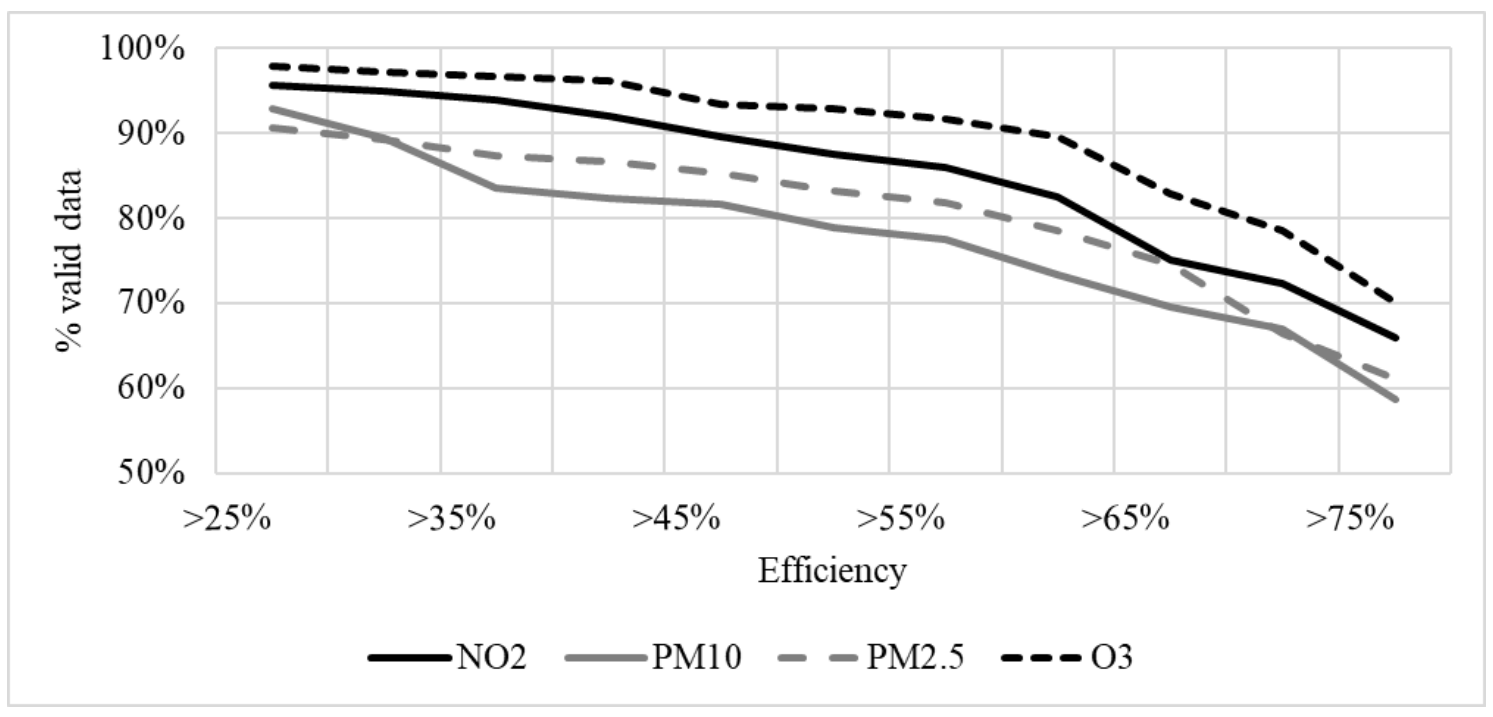

Figure 2. The influence of the efficiency criteria on the percentage of valid data.

\subsection{Description of the Air Quality Index Adopted}

To have information on the historical trend of air quality instead of that of single pollutants, the EU-AQI was adopted with some minor modifications in the calculation procedure.

The EU-AQI is a daily air quality index that assumes numerical values from 1 to 5 , corresponding with five air quality categories: very good, good, medium, poor, and very poor. The pollutants considered are five: $\mathrm{O}_{3}, \mathrm{NO}_{2}, \mathrm{SO}_{2}, \mathrm{PM} 10$, and PM2.5. The scheme to evaluate the EU-AQI is depicted in Table 2.

Table 2. The scheme of the EU-AQI.

\begin{tabular}{cccccc}
\hline & \multicolumn{5}{c}{ Index Level } \\
\cline { 2 - 6 } Pollutant & \multicolumn{5}{c}{ Based on Pollutant Concentrations in $\boldsymbol{\mu g} / \mathbf{m}^{\mathbf{3}}$} \\
\cline { 2 - 6 } & $\mathbf{1}$ & $\mathbf{2}$ & $\mathbf{3}$ & $\mathbf{4}$ & $\mathbf{5}$ \\
\cline { 2 - 5 } & Very Good & Good & Medium & Poor & Very Poor \\
\hline $\mathrm{NO}_{2}$ & $0-40$ & $40-100$ & $100-200$ & $200-400$ & $400-1000$ \\
$\mathrm{PM} 10$ & $0-20$ & $20-35$ & $35-50$ & $50-100$ & $100-200$ \\
$\mathrm{PM} 2.5$ & $0-10$ & $10-20$ & $20-25$ & $25-50$ & $50-800$ \\
$\mathrm{O}_{3}$ & $0-80$ & $80-120$ & $120-180$ & $180-240$ & $240-600$ \\
\hline
\end{tabular}

First, a daily sub-index is calculated for each pollutant by linear interpolation (Equation (3)) of the measured pollutant concentrations between the concentration levels in $\mu \mathrm{g} / \mathrm{m}^{3}$ reported in Table 2 .

$$
\mathrm{SI}_{\mathrm{g}, \mathrm{i}}=\mathrm{Y}+[\mathrm{i}]-[\mathrm{Y}]_{\min }[\mathrm{Y}]_{\max }-[\mathrm{Y}]_{\min }
$$

where $[Y]$ min and $[Y]$ max are the minimum and maximum concentrations of the range to which the index refers, respectively.

Then, the daily EU-AQI is assumed as the maximum of the calculated sub-indices (Equation (4)).

$$
\mathrm{AQI}_{\mathrm{s}, \mathrm{g}}=\max \left(\mathrm{SI}_{\mathrm{g}, \mathrm{i}}\right)
$$

We introduce some modifications in the evaluation of the EU-AQI due to the absence of all the mandatory data but maintain the significance of the result: (i) $\mathrm{SO}_{2}$ concentration is generally low, and its sub-index is never the maximum. Therefore, it does not contribute 
to the EU-AQI. For this reason, $\mathrm{SO}_{2}$ was not considered in our calculation. (ii) In traffic stations, the absence of $\mathrm{O}_{3}$ data was not considered a limitation to calculating the EU-AQI; (iii) in the same way, if one set of data was absent between PM10 or PM2.5, the EU-AQI was evaluated anyway.

\subsection{Method for Calculating the Impact on Human Health}

AirQ+ is a software developed by the WHO to quantify the impact of air pollution on health due to PM2.5, PM10, $\mathrm{NO}_{2}, \mathrm{O}_{3}$, and black carbon (BC). For each pollutant, the software allows us to develop two possible impact perspectives: acute effects related to short-term exposure, and chronic effects related to long-term exposure. AirQ+ is based on methodologies and functions that associate a certain health response to different levels of pollution, all based on epidemiological studies and the systematic review and meta-analysis of the data available up to 2013, mainly carried out by studies conducted in Western Europe and North America.

For inputs, the software requires (i) air quality data (the annual average concentration for long-term exposure effects or daily average concentration for short-term exposure); (ii) data of the population at risk (for example, the total number of adults aged $\geq 30$ years); (iii) the health data of the resident population; (iv) a limit value to be taken into account (e.g., $10 \mu \mathrm{g} / \mathrm{m}^{3}$ for PM2.5 as recommended by WHO) [36]; (v) population data and mortality data, both stratified by age, when using the life table analysis.

By default, the software provides relative risk values (RR) which estimate the extent of the association between exposure and a specific health endpoint. It estimates the probability with a $95 \%$ confidence interval of obtaining a certain effect on health in the exposed population compared to an unexposed population.

For the calculation of relative risk (RR), the software uses the following log-linear function:

$$
R R(x)=e \beta(x-x 0)
$$

where $\beta$ is the change in RR for a change of one unit of concentration; $x$ is the concentration of the pollutant; and $x_{0}$ is a limit value (cut-off).

Associating the exposed population $(P)$ with the relative risk $(R R)$, the attributable proportion $(A P)$ is the attributed fraction of the health endpoint due to exposure in a given population and can be calculated using

$$
A P=\Sigma(R R-1) \cdot P / \Sigma(R R \cdot P)
$$

From the $A P$, the rate (or the number of cases per population unit) attributed to exposure $(B E)$ in the population $(B)$ is calculated as

$$
B E=B \cdot A P
$$

For a population of a given size $N$, this can be converted into the estimated number of cases attributed to exposure:

$$
N E=B E^{*} N
$$

Consequently, the frequency of the outcome in the exposure-free population can be estimated as

$$
B N E=B-B E=B *(1-A P)
$$

In this work, only the chronic effects are calculated. Starting from the hourly data obtained from the ARPAC, the daily averages for each pollutant at each station are obtained. To get a valid 24 -h average, an efficiency criterion $>75 \%$ is fixed, i.e., at least 18 hourly average values out of 24 are necessary. Then, an annual average is evaluated if at least $50 \%$ of the 24 -h valid average concentration data are available in the year.

The results obtained are the mortality (for all ages) for $\mathrm{NO}_{2}$, the incidence of chronic bronchitis in adults for PM10, and the incidence of mortality in the adult population (>30 years) for PM2.5. 
The "incidence" data refers to the basic incidence of a certain effect on the health of the exposed population. Since, in this case, we refer to mortality associated with all age groups, then we insert the mortality index of the population exposed to the risk, which is the total one.

The results obtained are expressed by the program in three equivalent forms:

- The estimated percentage;

- The number of cases compared to the exposed population;

- The number of cases per 100,000 people exposed.

The result indicates, for a given health endpoint, the percentage of cases that could be avoided if the pollutant concentration did not exceed the threshold indicated by us in the cut-off value which coincides with WHO air quality guidelines.

AirQ+ is a useful software to determine the exposure to the air pollution and was developed on the basis of the scientific evidence evaluated within expert groups in determining the air pollutant-health outcome relationships. For this reason, AirQ+ has been often used in studying the health impacts of poor air quality. However, the tool needs some improvements to minimize its limitations, in particular, for some air pollutants such as NO2, BC, and ozone (long-term exposure), where the evidence of health outcome relationships is not as strong [29] and for evaluating the risk related to air pollution mixtures and not only to single pollutants [37].

\section{Results}

\subsection{Historical Trends of Pollutants}

The historical trends are represented for each pollutant through several parameters: the number of times the limit value is exceeded and the annual average, or percentiles. Due to the large amount of data, data are spatially averaged per province. The number of exceedances is obtained by summing all the exceedances registered in the stations of the same province and dividing them by the number of stations active in that year. The annual average and percentiles are calculated as the average of all the receptors present in the same province.

Figure 3a shows, for $\mathrm{NO}_{2}$, the number of exceedances of the 1-h average limit value of $200 \mu \mathrm{g} / \mathrm{m}^{3}$ evaluated as the total number of exceedances registered in each province per year divided by the number of active receptors. Figure $3 b$ reports, for each province, the annual $\mathrm{NO}_{2}$ average of all the active $\mathrm{NO}_{2}$ receptors in the year. Even though data of some years (2004, 2005, and 2013) are missing for all provinces because the monitoring efficiency was below the efficiency criteria adopted ( $>50 \%$ of data in the year), Figure $3 a, b$ clearly show a decreasing trend of $\mathrm{NO}_{2}$. In fact, since 2016, the average number of exceedances per province is near to zero, and the annual average is below the limit value of $40 \mu \mathrm{g} / \mathrm{m}^{3}$ (Figure 3), while before 2010 the number of exceedances was often higher than 5, and the annual average higher than the limit value of $40 \mu \mathrm{g} / \mathrm{m}^{3}$.

Two statistical parameters are explored to analyze the historical trend of PM10, the number of exceedances of the 24-h limit value of $50 \mu \mathrm{g} / \mathrm{m}^{3}$, and the average annual concentration. In both cases, they are the average values in the province (Figure 4).

Additionally, in this case, there is a lack of data for 2004, 2005, 2010, and 2013. Therefore, the individuation of a trend is more difficult. In general, an increasing trend is observed from 2007 to 2009 . However, from 2015 to 2019, a reduction in the concentrations of PM10 is registered. In Figure 4b, from 2015, the average annual concentration is always lower than the limit value of $40 \mu \mathrm{g} / \mathrm{m}^{3}$, but the guideline imposed by the WHO of $20 \mu \mathrm{g} / \mathrm{m}^{3}$ is always exceeded. 

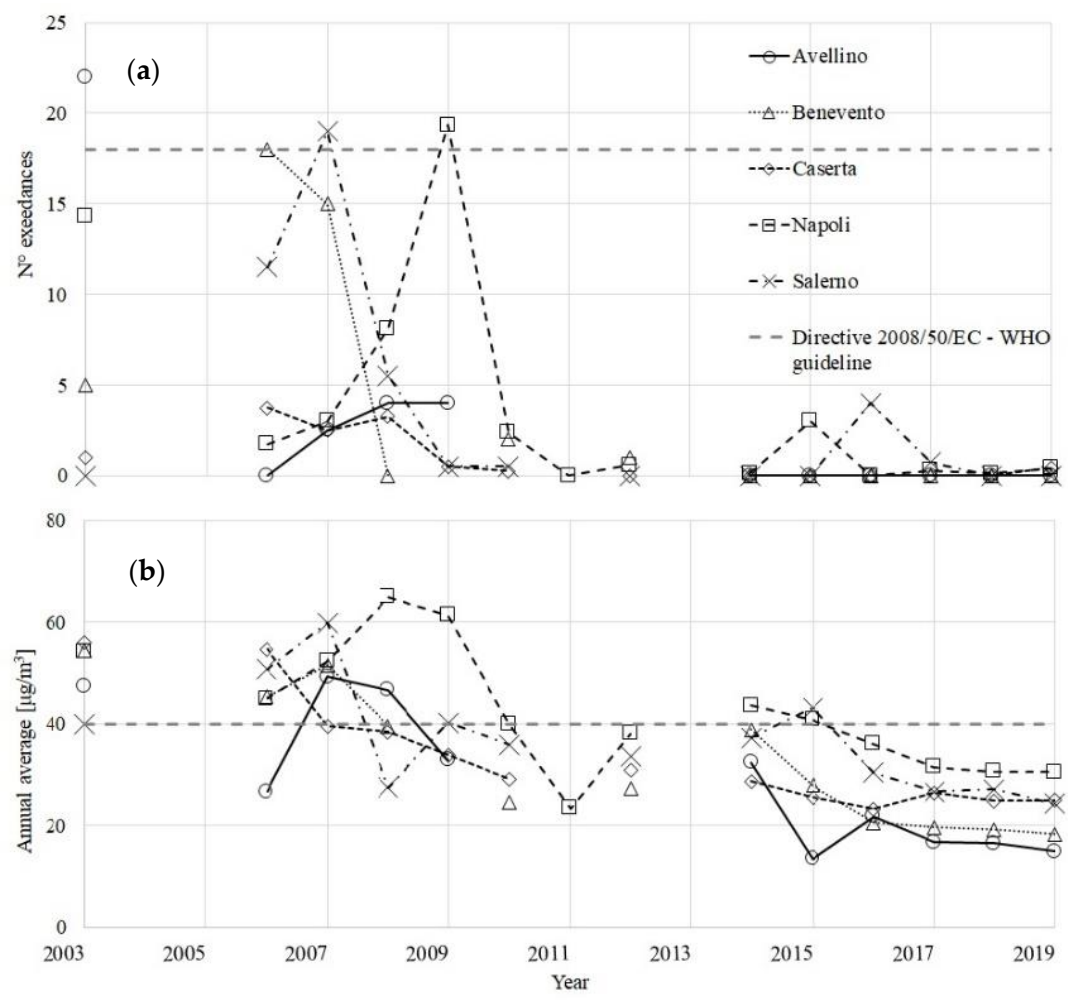

Figure 3. Average $\mathrm{NO}_{2}$ values per province. (a): the number of exceedances of the 1-h limit value of $200 \mu \mathrm{g} / \mathrm{m}^{3}$; (b): the annual concentration values.

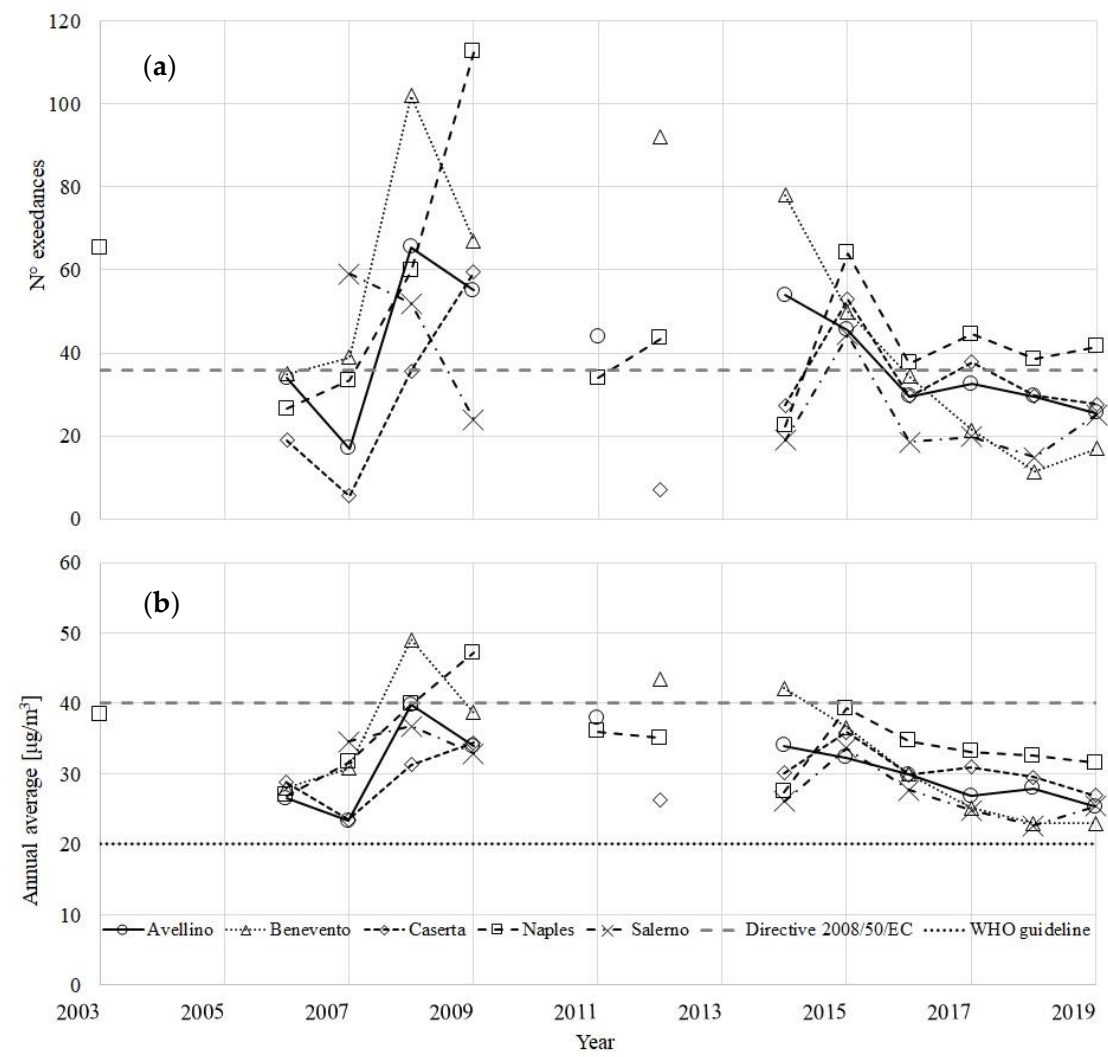

Figure 4. Average PM10 values per province. (a): the number of exceedances of the 24-h limit value of $50 \mu \mathrm{g} / \mathrm{m}^{3}$; (b): the annual average concentration values. 
The monitoring of PM2.5 in the Campania region started in 2007. Therefore, less data is available with respect to other pollutants. Considering the annual average, a reduction is evident starting in 2015 (Figure 5). All the provinces are within the European limit value of $25 \mu \mathrm{g} / \mathrm{m}^{3}$, but the guideline of $10 \mu \mathrm{g} / \mathrm{m}^{3}$ proposed by the WHO [38] is still exceeded (Figure 5).

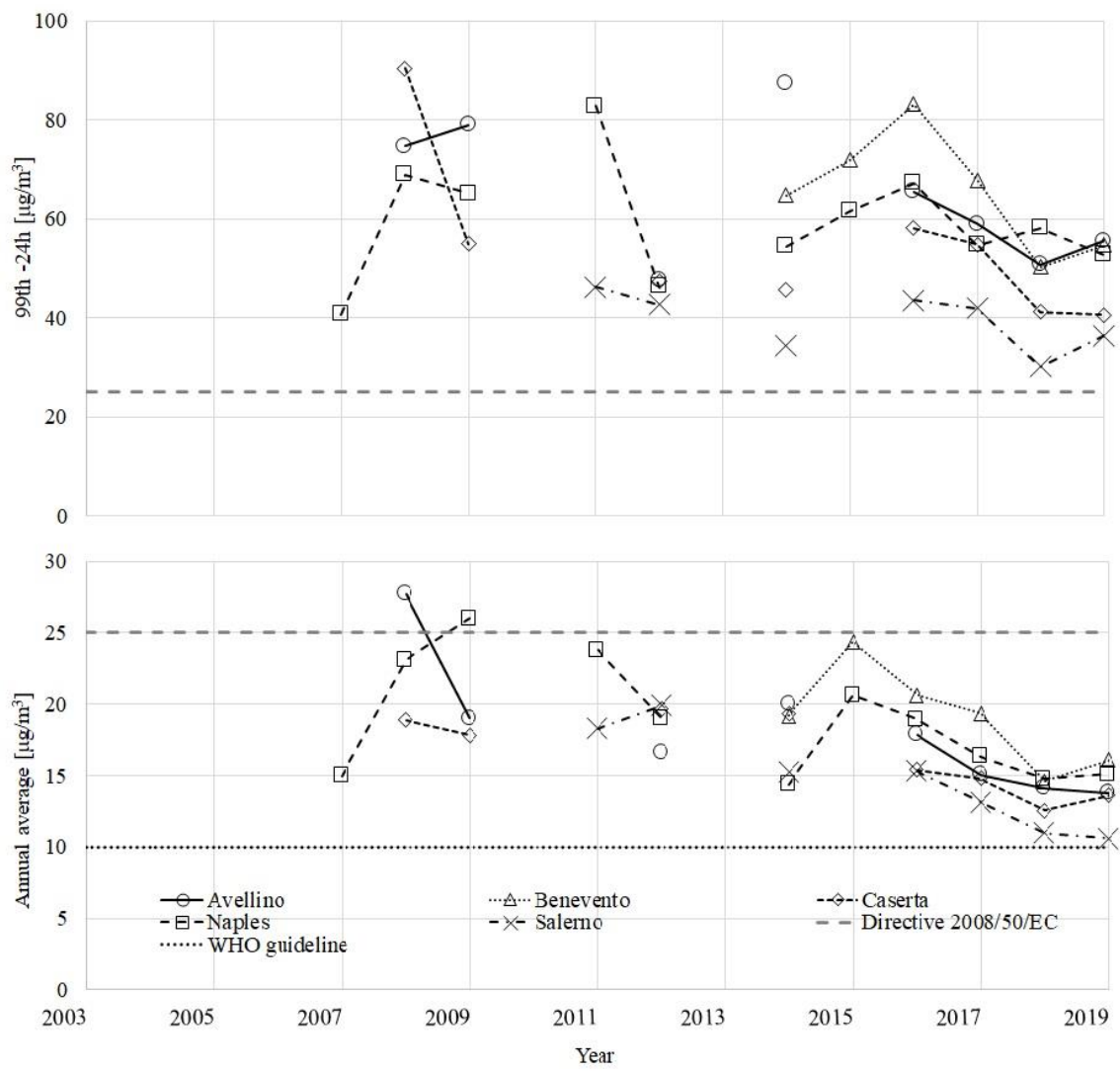

Figure 5. Average PM2.5 values per province. (Up): the 99th percentile of 24-h concentrations; (bottom): the annual average concentration values.

The historical trend of $\mathrm{O}_{3}$ is shown in Figure 6, where the average number of exceedances, per province, of the EU-limit value of $120 \mu \mathrm{g} / \mathrm{m}^{3}$ of the maximum daily values of 8-h mobile average is reported. Due to the scatter of data, it is not possible to clearly identify any trend. However, since 2016, an increasing trend is evident for two provinces (Avellino and Salerno). The highest average number of exceedances is observed in the province of Avellino, which has the highest average level on the sea.

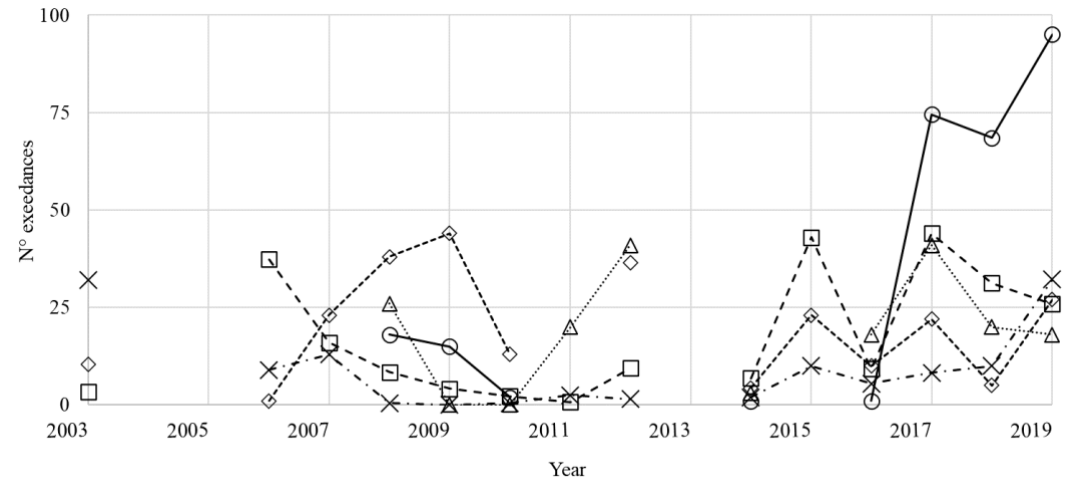

Figure 6. $\mathrm{O}_{3}$ : the number of exceedances beyond the limit of $120 \mu \mathrm{g} / \mathrm{m}^{3}$ (Directive 2008/50/EC). 


\subsection{Historical Trends of the EU-AQI}

The historical trend of air quality is reported in Figure 7 as the percentage of days in which the EU-AQI was greater than or equal to 3 (air quality from medium to very poor).

The EU-AQI annual for each province is evaluated by dividing the number of times that the EU-AQI is greater than or equal to 3 by the number of days in which the EU-AQI was evaluated for all stations in each province. Figure 7 shows a peak of air pollution in 2009 and an improvement in air quality since 2016. In fact, the percentage of the occurrences of EU-AQI $\geq 3$ decreases from 2016 to 2019.

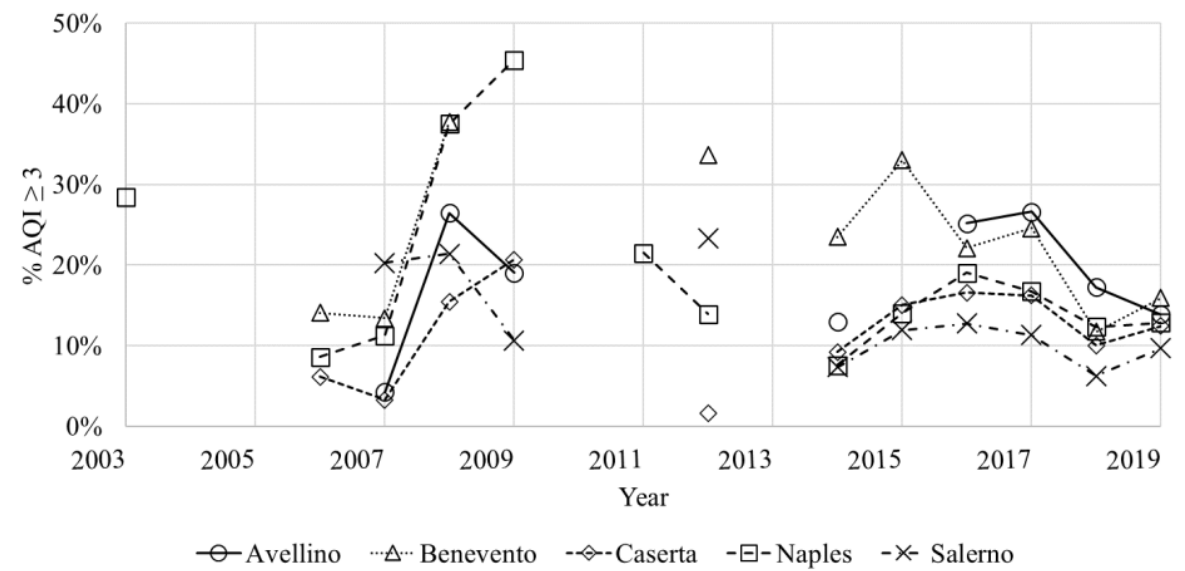

Figure 7. The historical trend of EU-AQI in provinces of the Campania region.

\subsection{Historical Trends of the Impact on the Human Health}

The impact of air pollution on human health in Campania was evaluated using the software AIRQ+, as described in the Methodology section, from 2003 to 2018. The results are reported in Figure 8.

The trend of the impact of $\mathrm{NO}_{2}$ measured as the percentage of mortality cases due to all natural causes attributable to $\mathrm{NO}_{2}$ concentrations is clearly decreasing (Figure 8 (up)), passing from a maximum of $10 \%$ in 2010 to values $<4 \%$ in 2018 . Generally, the highest percentages are observed in the province of Naples. A less-clear decreasing trend is also observed for PM10 (Figure 8 (middle)) since 2008. In this case, the effect is measured as the percentage of cases of chronic bronchitis and hospitalizations for respiratory diseases attributable to PM10. Finally, the bottom diagram of Figure 8 shows the percentage of cases of mortality from natural causes, such as COPD, lung cancer mortality, mortality from ischemia, and mortality from stroke related to adulthood (30+) attributable to PM2.5 concentrations. Additionally, for PM2.5, a decreasing trend is observed since 2010.

In general, for all three pollutants, the impact on human health decreases over time. This is consistent with the previously reported decreasing concentration trends. 


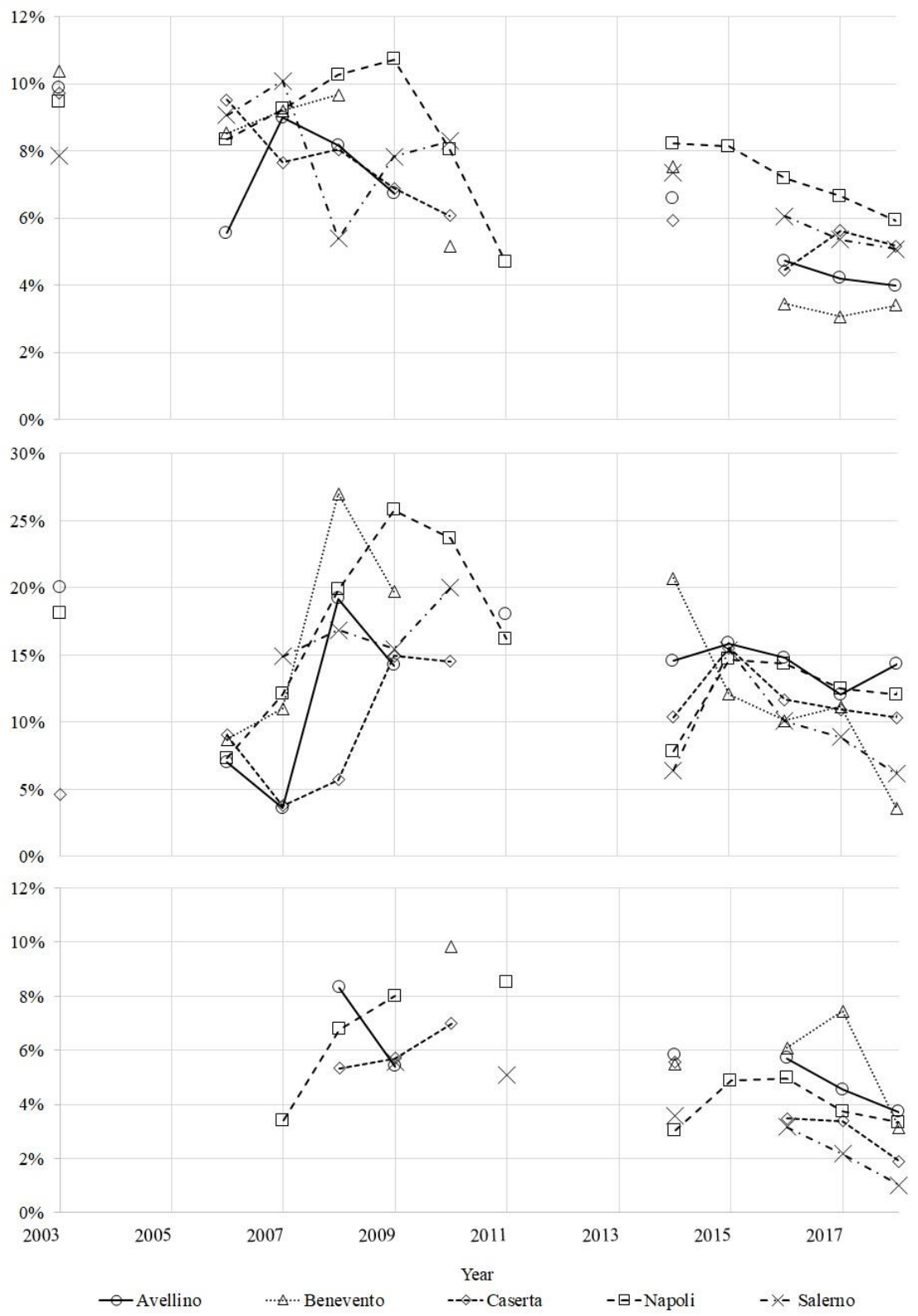

Figure 8. The impact on human health. Estimates of the attributable proportions percentages for $\mathrm{NO}_{2}$ (up), PM10 (middle), and PM2.5 (bottom).

\subsection{Discussion of Results}

It is now necessary to highlight the limitations of the study. The main limitation relates to the missing data in some years due to poor monitoring efficiency, and the fact that some datasets do not meet the assumed quality criteria. Moreover, the analysis is focused exclusively on $\mathrm{NO}_{2}, \mathrm{PM} 10, \mathrm{PM} 2.5$, and $\mathrm{O}_{3}$. Other pollutants were not considered for different reasons. Data on benzene and $\mathrm{SO}_{2}$ were available only in few monitoring stations. Moreover, $\mathrm{SO}_{2}$ concentrations are generally very low; polycyclic aromatic hydrocarbons (PAHs) were not monitored routinely. CO was excluded from the analysis because its concentration levels are largely below the legislative limits.

Another limitation is the spatial representativeness of the fixed stations. Most of the streets in the largest urban agglomerates in Campania are narrow, and fixed stations cannot be installed. They are generally deep street canyons with an aspect ratio (heightto-width ratio) $\mathrm{H} / \mathrm{W}>2$ [39]. Information on the air quality in these streets is largely incomplete and derived only from spot-monitoring campaigns. However, all of these 
indicate a critical situation, with concentration levels of benzene, carbon oxide, and particle number concentrations higher than those measured at the same time at the nearest fixed stations of the regional air quality network [40-42].

In spite of these limitations, the results reported give a clear indication of a decreasing historical trend of air pollution with respect to $\mathrm{NO}_{2}$, and a less evident one for PM10 and PM2.5. These findings are in agreement with those reported in the annual report on air quality in urban areas in Italy [43].

With the aim to get some findings on the possible causes determining the improvement of air quality in the Campania region, data reported in Figures 3-6 were re-evaluated, lumping all stations into two categories: "background-industrial" and "traffic" (Figures 9 and 10).
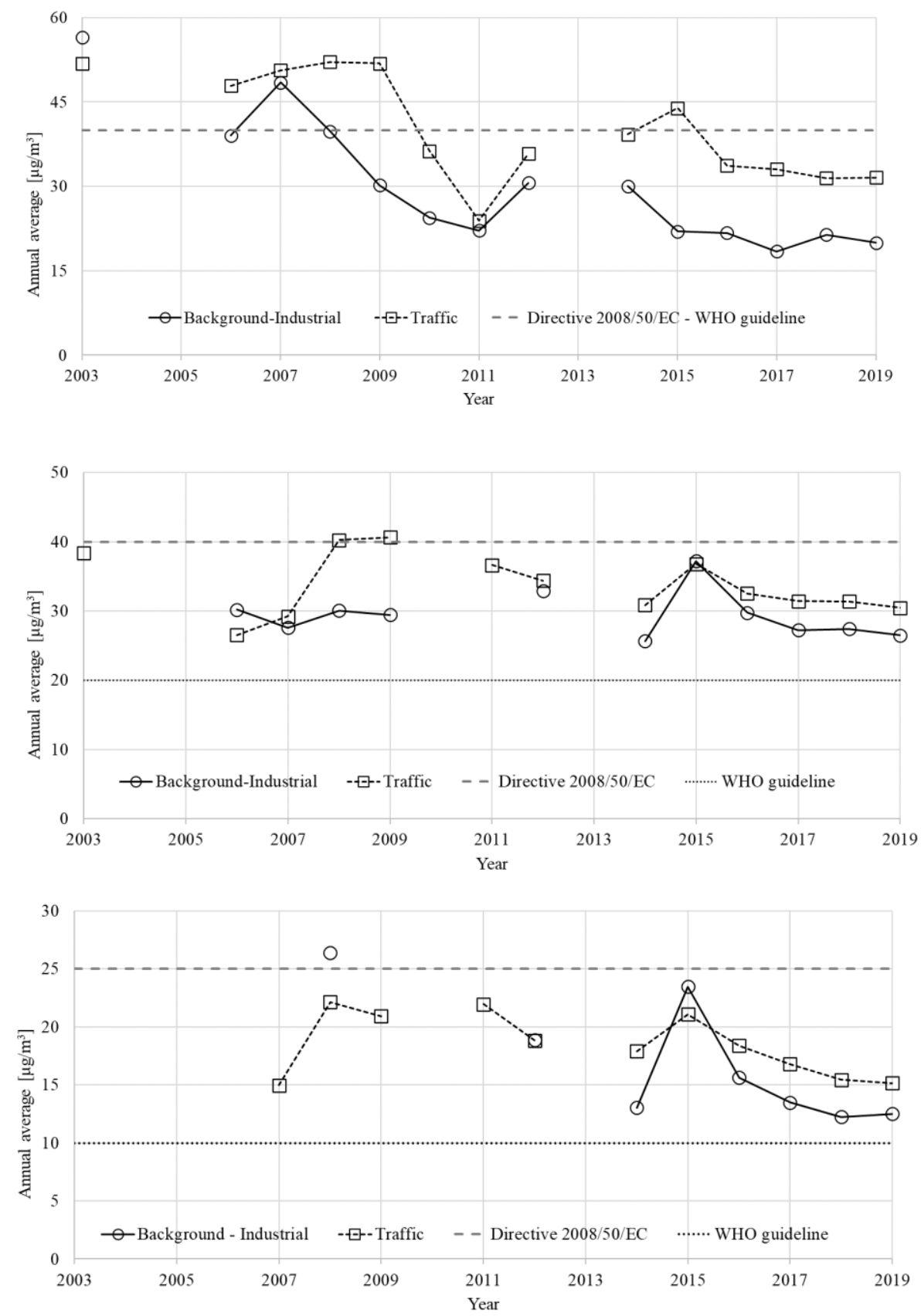

Figure 9. The average annual concentrations per station category: $\mathrm{NO}_{2}$ (up); PM10 (middle); PM2.5 (bottom). 


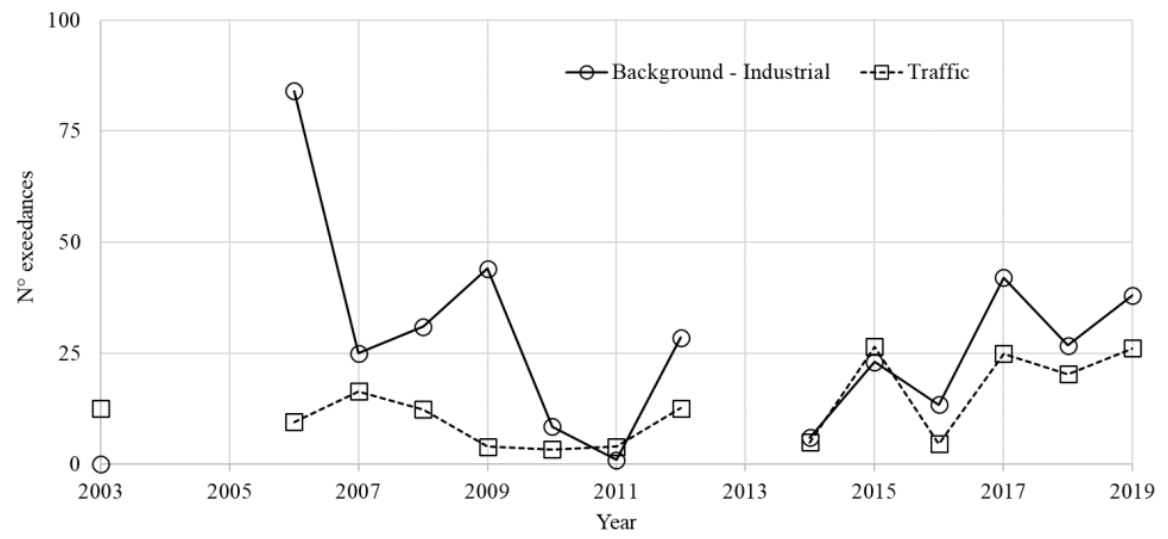

Figure 10. The number of exceedances of the $\mathrm{O}_{3}$ limit according to the EU threshold of $120 \mu \mathrm{g} / \mathrm{m}^{3}$.

The historical trends reported are confirmed. Traffic stations have higher pollution levels with respect to $\mathrm{NO}_{2}, \mathrm{PM} 10$, and PM2.5, while ozone concentration is higher in background-industrial stations. However, no significant differences are observed between the trends of the two categories.

As reported in the Methodology section, the daily quality index EU-AQI is determined by the pollutant with the highest sub-index in the day. It is interesting to determine which pollutant most frequently determines the EU-AQI value. Figure 11 shows, for each pollutant, the percentage of occurrences of the maximum sub-index (the number of days with a maximum sub-index divided by the number of validated daily quality indexes in the year) from 2003 to 2019 across the whole region. It is evident that PM (PM10 and PM2.5) plays a dominant role from 2014 to 2019, with the maximum daily sub-index generally being met in more than $50 \%$ of traffic stations (Figure 11 (bottom)). It is also evident that, in the same period, ozone has an increasing trend in the industrial-background stations (Figure 11 (up)).
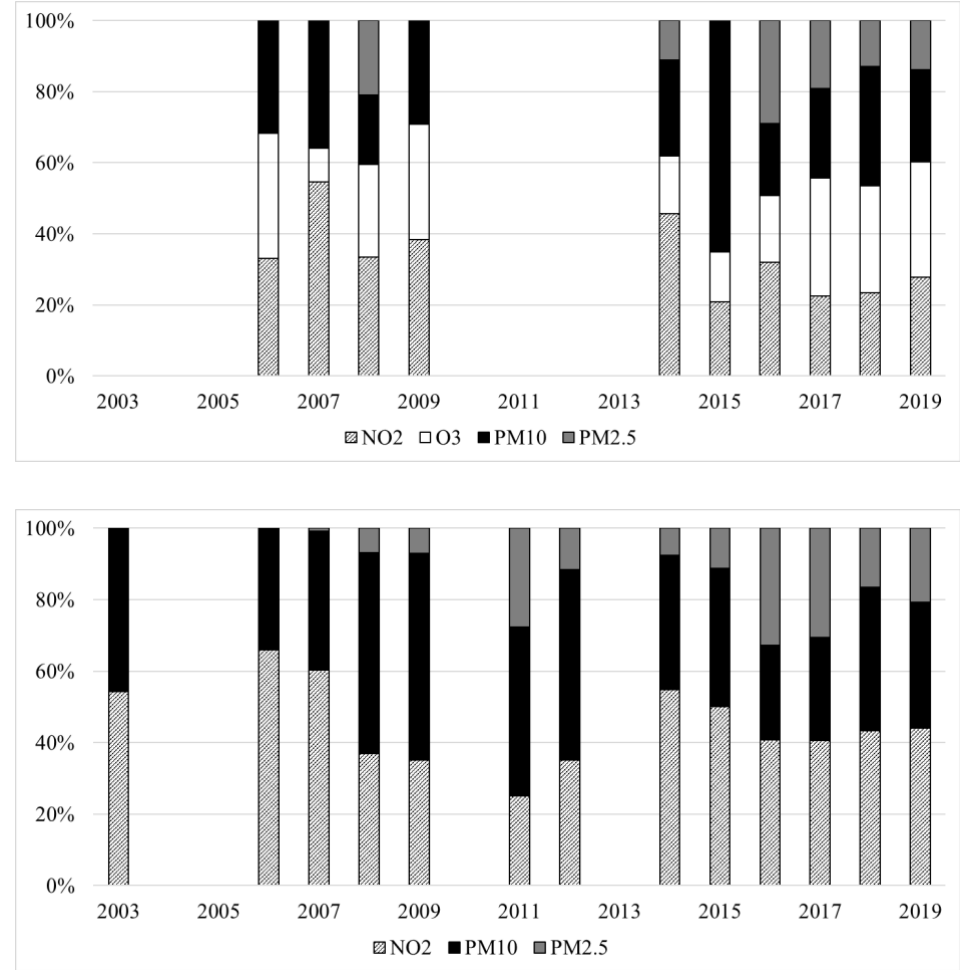

Figure 11. The percentage of days in which the maximum daily sub-index is met in industrialbackground (up) and traffic (bottom) stations. 
Since vehicular traffic is one of the main sources of NOx, the historical trend of the four-wheel vehicular fleet composition is reported in Figure 12. A reduction of the percentage of the old EURO classes (EURO 0-2-3) can be observed, with an increase of the new EURO classes (EURO 4-5-6). The EURO 4-5-6 technologies represent those with the highest reduction in NOx emissions, and their percentage from 2015 to 2019 increased from $45 \%$ to $60 \%$.

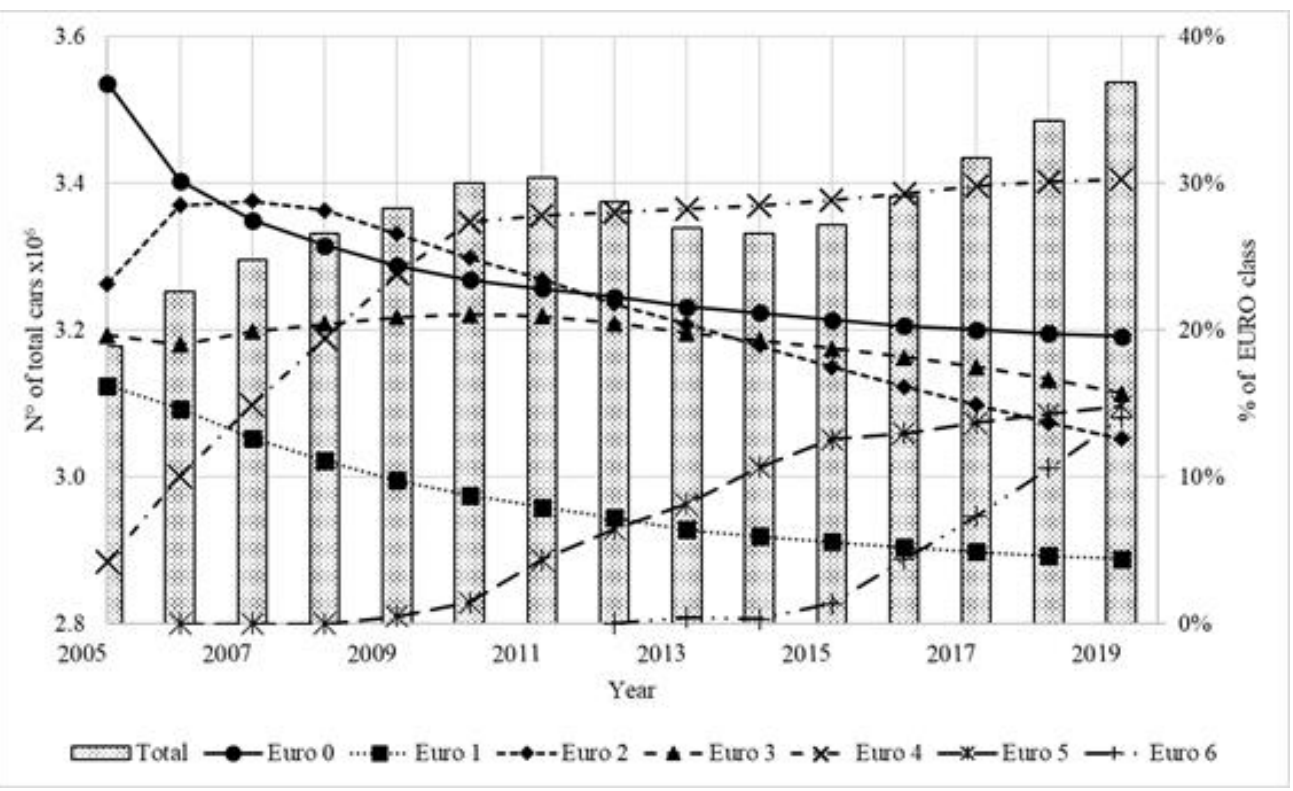

Figure 12. The historical trends of fleets of four-wheel vehicles in Campania.

It is interesting to observe the different spatial distribution of $\mathrm{NO}_{2}, \mathrm{PM} 10$, and $\mathrm{O}_{3}$. Contour maps referring to annual averages in 2019 (Figure 13) show how $\mathrm{NO}_{2}$ is quite high in urban areas (Naples and Salerno), while $\mathrm{O}_{3}$ is prevalent in suburban and rural areas.

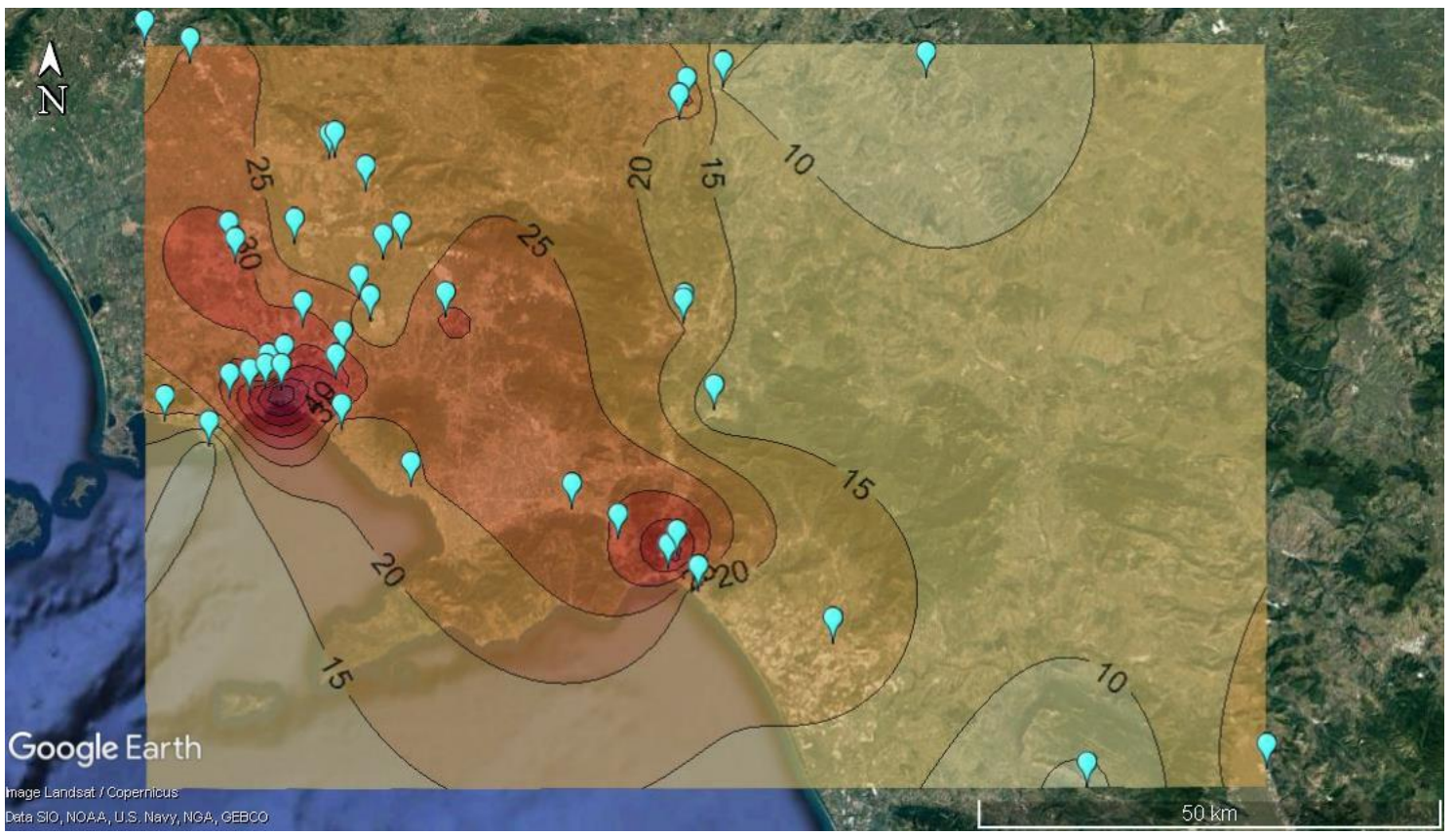

$\mu \mathrm{g} / \mathrm{m}^{3}$

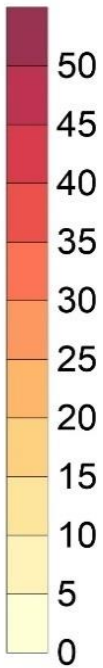

Figure 13. Cont. 


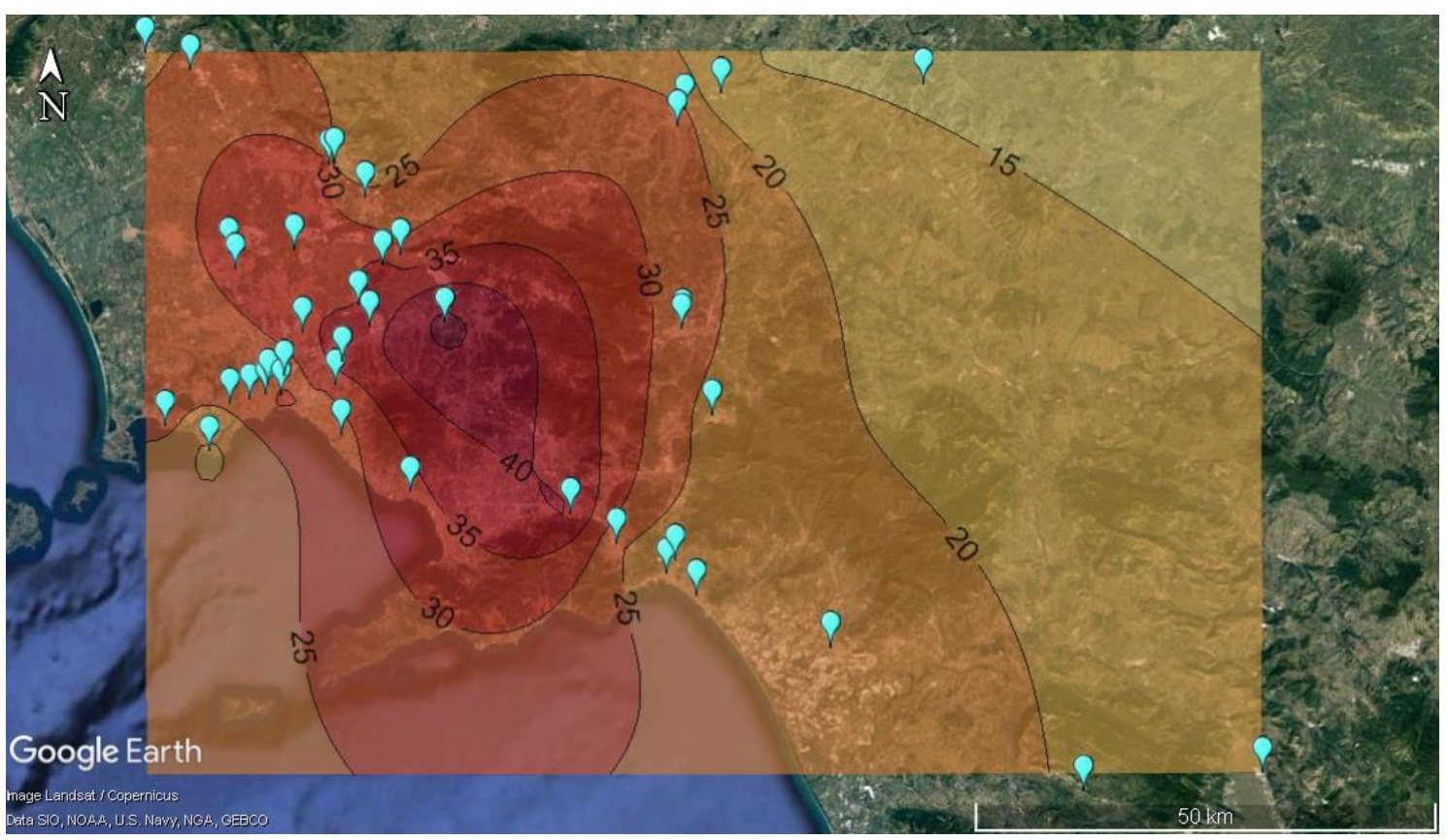

$$
\begin{aligned}
& \mu \mathrm{g} / \mathrm{m}^{3} \\
& 45 \\
& 40 \\
& 35 \\
& 30 \\
& 25 \\
& 20 \\
& 15 \\
& 10 \\
& 5 \\
& 0
\end{aligned}
$$
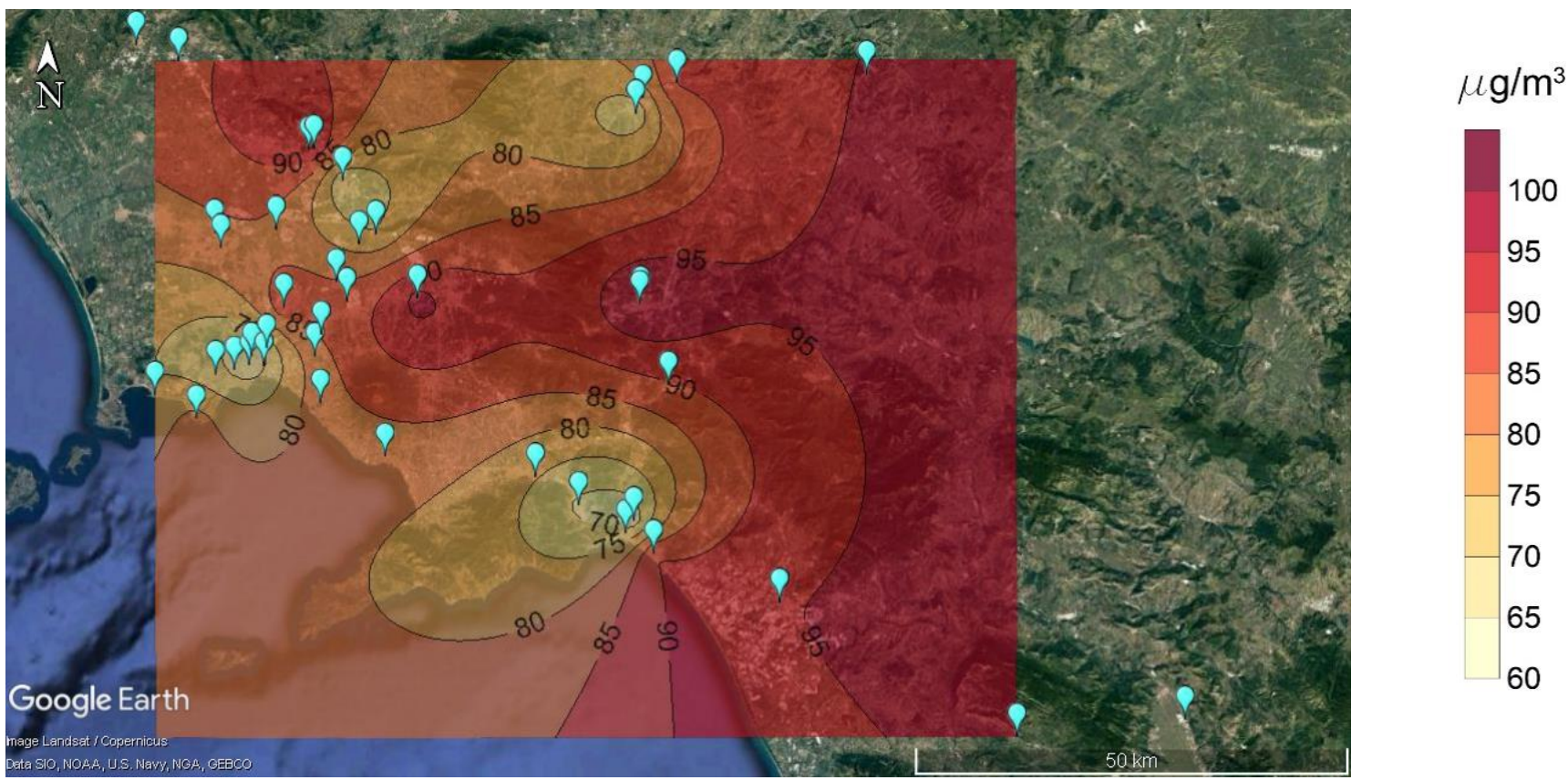

Figure 13. Maps of the annual averages for 2019. $\mathrm{NO}_{2}$ (up); PM10 (middle); $\mathrm{O}_{3}$ (bottom).

\section{Conclusions}

The study analyzes the historical trends of air quality in the Campania region from 2003 to 2019. The trends for $\mathrm{NO}_{2}, \mathrm{PM} 10$, and PM2.5 are generally decreasing, in particular $\mathrm{NO}_{2}$. The decrease is less evident for PM10 and PM2.5, but in the former case, data are available only from 2007. Ozone shows an increasing trend from 2015 to 2019 in two provinces.

The trends measured through the EU-AQI confirm the results of single pollutants. PM10 and PM2.5 play a dominant role in determining the value of the EU-AQI, especially in traffic stations. However, in recent years, the prevalence of $\mathrm{O}_{3}$ is increasing, in particular at industrial-background stations. 
Additionally, the impact of air pollution on human health expressed in terms of attributable fractions shows generally a decreasing trend.

However, some limit values established by the European community are still not being respected, and the same goes for some $\mathrm{WHO}$ guidelines. Therefore, more efforts are necessary to reduce anthropogenic emissions.

The results of the study are limited due to missing data from years when the amount of data available does not meet the quality criteria. Another limitation is the incomplete representativeness of all the regional territory by the fixed stations. In fact, in the urban areas of Campania, many deep street canyons $(\mathrm{H} / \mathrm{W}>2)$ are present but are not monitored by fixed stations because they are very narrow. The results of several short-term monitoring campaigns performed inside the old center of Naples regarding benzene, $\mathrm{CO}$, and particle number concentration suggest alarmingly poor air quality. At present, knowledge regarding the human health impacts of the air quality in the deep street canyons of Campania's urban agglomerates requires further study. The implementation of pervasive monitoring campaigns with the use of low-cost sensors [44] could be a possible solution for the effective air quality monitoring of these streets.

Author Contributions: Conceptualization, D.T. and F.M.; methodology, D.T. and F.M.; software, D.T.; validation, D.T. and F.M.; formal analysis, D.T. and F.M.; investigation, D.T. and F.M.; resources, D.T.; data curation, D.T.; writing—original draft preparation, F.M.; writing—review and editing, D.T. and F.M. All authors have read and agreed to the published version of the manuscript.

Funding: This research received no external funding.

Institutional Review Board Statement: Not applicable.

Informed Consent Statement: Not applicable.

Data Availability Statement: Data used in this study are available at http:/ / cemec.arpacampania. it/meteoambientecampania/php/pubblicazione_dati_centraline_validati.php.

Acknowledgments: The authors are grateful to Giuseppe Onorati for making the data of the ARPAC monitoring stations available.

Conflicts of Interest: The authors declare no conflict of interest.

\section{References}

1. WHO. Burden of Disease from Ambient Air Pollution for 2012-Summary of Results, World Health Organization. 2014. Available online: http:/ / www.who.int/phe/health_topics/outdoorair/databases/AAP_BoD_results_March2014.pdf (accessed on 15 January 2021).

2. WHO, 2018a, WHO Global Ambient Air Quality Database (Update 2018), World Health Organization. Available online: https:/ / www.who.int/airpollution/data/en/ (accessed on 15 January 2021).

3. GBD 2016 Risk Factors Collaborators. Global, regional, and national comparative risk assessment of 84 behavioural, environmental and occupational, and metabolic risks or clusters of risks, 1990-2016: A systematic analysis for the Global Burden of Disease Study 2016. Lancet 2017, 390, 1345-1422. [CrossRef]

4. Akkina, R.; Garry, R.; Bréchot, C.; Ellerbrok, H.; Hasegawa, H.; Menéndez-Arias, L.; Mercer, N.; Neyts, J.; Romanowski, V.; Segalés, J.; et al. 2019 meeting of the global virus network. Antivir. Res. 2019, 172, 104645. [CrossRef]

5. Bezirtzoglou, C.; Dekas, K.; Charvalos, E. Climate changes, environment and infection: Facts, scenarios and growing awareness from the public health community within Europe. Anaerobe 2011, 17, 337-340. [CrossRef] [PubMed]

6. Linares, C.; Martinez, G.; Kendrovski, V.; Diaz, J. A new integrative perspective on early warning systems for health in the context of climate change. Environ. Res. 2020, 187, 109623. [CrossRef] [PubMed]

7. Huang, L.; Zhou, L.; Chen, J.; Chen, K.; Liu, Y.; Chen, X.; Tang, F. Acute effects of air pollution on influenza-like illness in Nanjing, China: A population-based study. Chemosphere 2016, 147, 180-187. [CrossRef] [PubMed]

8. Wang, K.-Y.; Chau, T.-T. An Association between Air Pollution and Daily Outpatient Visits for Respiratory Disease in a Heavy Industry Area. PLoS ONE 2013, 8, e75220. [CrossRef] [PubMed]

9. WHO. Review of Evidence on Health Aspects of Air Pollution-REVIHAAP Project; Technical Report; World Health Organization, Regional Office for Europe: Copenhagen, Denmark, 2013.

10. WHO. Effects of Air Pollution on Children's Health and Development-A Review of the Evidence; World Health Organization, Regional Office for Europe: Copenhagen, Denmark, 2005. 
11. RCP, 2016, Every Breath We Take: The Lifelong Impact of Air Pollution, Working Party Report, Royal College of Physicians, London. Available online: https://www.rcplondon.ac.uk/projects/outputs/every-breath-we-take-lifelongimpact-air-pollution (accessed on 15 January 2021).

12. WHO. WHO Expert Consultation: Available Evidence for the Future Update of the WHO Global Air Quality Guidelines (AQGs), World Health Organisation Regional Office for Europe, Copenhagen. 2016. Available online: http://www.euro.who.int/data/ assets /pdffile/0013/301720/Evidencefuture-update-AQGs-mtg-report-Bonn-sept-oct-15.pdf?ua=1 (accessed on 15 January 2021).

13. Guerreiro, C.; Ortiz, A.G.; de Leeuw, F.; Viana, M.; Horálek, J. Air Quality in Europe-2016 Report; Publications Office of the European Union: Luxembourg, 2016.

14. NASA Earth Observatory. Available online: https://earthobservatory.nasa.gov/images/15900/smog-in-northern-italy (accessed on 15 January 2021).

15. Ancona, C.; Golini, M.N.; Ciancarella, L.; Demaria, M.; Badaloni, C.; Cesaroni, G.; Cadum, E.; Forastirere, F. Health Impact Assessment of PM2.5 And $\mathrm{NO}_{2}$ In Italy. The VIIAS National Study. ISEE Conf. Abstr. 2015, 1, 1. [CrossRef]

16. Bortnick, S.M.; Coutant, B.W.; Eberly, S.I. Using Continuous PM2.5 Monitoring Data to Report an Air Quality Index. J. Air Waste Manag. Assoc. 2002, 52, 104-112. [CrossRef]

17. Murena, F. Measuring air quality over large urban areas: Development and application of an air pollution index at the urban area of Naples. Atmospheric Environ. 2004, 38, 6195-6202. [CrossRef]

18. Ott, W.R.; Hunt, W.F., Jr. A quantitative evaluation of the pollutant standards index. J. Air Pollut. Control Assoc. 1976, 26, 1050-1054. [CrossRef]

19. Fitz-Simons, T. Guideline for Reporting of Daily Air Quality: Air Quality Index (AQI) (No. PB-99-169237/XAB; EPA-454/R-99/010); Environmental Protection Agency, Office of Air Quality Planning and Standards: Research Triangle Park, Durham, NC, USA, 1999.

20. Hoek, G.; Krishnan, R.M.; Beelen, R.; Peters, A.; Ostro, B.; Brunekreef, B.; Kaufman, J.D. Long-term air pollution exposure and cardio- respiratory mortality: A review. Environ. Heal. 2013, 12, 43. [CrossRef]

21. Cohen, A.J.; Brauer, M.; Burnett, R.; Anderson, H.R.; Frostad, J.; Estep, K.; Balakrishnan, K.; Brunekreef, B.; Dandona, L.; Dandona, R.; et al. Estimates and 25-year trends of the global burden of disease attributable to ambient air pollution: An analysis of data from the Global Burden of Diseases Study 2015. Lancet 2017, 389, 1907-1918. [CrossRef]

22. Bloemsma, L.D.; Wijga, A.H.; Klompmaker, J.O.; Janssen, N.A.; Smit, H.A.; Koppelman, G.H.; Brunekreef, B.; Lebret, E.; Hoek, G.; Gehring, U. The associations of air pollution, traffic noise and green space with overweight throughout childhood: The PIAMA birth cohort study. Environ. Res. 2019, 169, 348-356. [CrossRef]

23. Dobaradaran, S.; Geravandi, S.; Goudarzi, G.; Idani, E.; Salmanzadeh, S.; Soltani, F.; Yari, A.R.; Mohammadi, M.J. Determination of cardiovascular and respiratory diseases caused by PM10 exposure in Bushehr, 2013. J. Maz. Univ. Med. Sci. 2016, $26,42-52$.

24. Hadei, M.; Shahsavani, A.; Krzyzanowski, M.; Querol, X.; Stafoggia, M.; Nazari, S.S.H.; Jafari, A.J.; Yarahmadi, M.; Kermani, M.; Khosravi, A. Burden of mortality attributed to PM2.5 exposure in cities of Iran; contribution of short-term pollution peaks. Atmos. Environ. 2020, 224, 117365. [CrossRef]

25. Khaefi, M.; Geravandi, S.; Hassani, G.; Yari, A.R.; Soltani, F.; Dobaradaran, S.; Moogahi, S.; Mohammadi, M.J.; Mahboubi, M.; Alavi, N. Association of particulate matter impact on prevalence of chronic obstructive pulmonary disease in Ahvaz, southwest Iran during 2009-2013. Aerosol Air Qual. Res. 2017, 17, 230-237. [CrossRef]

26. Klepac, P.; Locatelli, I.; Korošec, S.; Künzli, N.; Kukec, A. Ambient air pollution and pregnancy outcomes: A comprehensive review and identification of environmental public health challenges. Environ. Res. 2018, 167, 144-159. [CrossRef]

27. Sówka, I.; Nych, A.; Kobus, D.; Bezyk, Y.; Zathey, M. Analysis of exposure of inhabitants of Polish cities to air pollution with particulate matters with application of statistical and geostatistical tools. In E3S Web of Conferences; EDP Sciences: Les Ulis, France, 2019; Volume 100, p. 00075.

28. Ansari, M.; Ehrampoush, M.H. Meteorological correlates and AirQ+ health risk assessment of ambient fine particulate matter in Tehran, Iran. Environ. Res. 2019, 170, 141-150. [CrossRef]

29. Sacks, J.D.; Fann, N.; Gumy, S.; Kim, I.; Ruggeri, G.; Mudu, P. Quantifying the Public health benefits of reducing air pollution: Critically assessing the features and capabilities of WHO's AirQ+ and US EPA's environmental benefits mapping and analysis program-Community edition (BenMAP-CE). Atmosphere 2020, 11, 516. [CrossRef]

30. Rovira, J.; Domingo, J.L.; Schuhmacher, M. Air quality, health impacts and burden of disease due to air pollution (PM10, PM2.5, NO2 and O3): Application of AirQ+ model to the Camp de Tarragona County (Catalonia, Spain). Sci. Total. Environ. 2020, 703, 135538. [CrossRef]

31. Koppen, W. Das geographische System der Klimate. In Handbuch der Klimatologie 3; Köppen, W., Geiger, R., Eds.; Gebrueder Borntraeger: Berlin, Germany, 1936; 46p.

32. Ducci, D.; Tranfaglia, G. L'impatto dei cambiamenti climatici sulle risorse idriche sotterranee della Campania. Geologi Boll Ordine Geologi Della Campania 2005, 1, 13-21.

33. Toscano, D.; Murena, F. The Effect on Air Quality of Lockdown Directives to Prevent the Spread of SARS-CoV-2 Pandemic in Campania Region-Italy: Indications for a Sustainable Development. Sustainability 2020, 12, 5558. [CrossRef] 
34. Murena, F.; D'Ambrosio, M.G.; Toscano, D. Assessment of air quality and analysis of representativeness of fixed stations from data of a regional air quality network. In Proceedings of the Seventh International Conference on Environmental Management, Engineering, Planning and Economics (CEMEPE 2019) and SECOTOX Conference, Mykonos Island, Greece, $19-24$ May 2019.

35. European Commission. Directive 2008/50/EC of the European Parliament and of the Council of 21 May 200 on ambient air quality and cleaner air for Europe. Off. J. Eur. Union 2008, 152, 1-44.

36. WHO. Evolution of Who Air Quality Guidelines: Past, Present and Future; WHO Regional Office for Europe: Copenhagen, Denmark, 2017.

37. Amoatey, P.; Sicard, P.; De Marco, A.; Khaniabadi, Y.O. Long-term exposure to ambient PM2. 5 and impacts on health in Rome, Italy. Clin. Epidemiol. Glob. Health. 2020, 8, 531-535. [CrossRef]

38. World Health Organization. Air Quality Guidelines: Global Update 2005: Particulate Matter, Ozone, Nitrogen Dioxide, and Sulfur Dioxide; World Health Organization: Geneva, Switzerland, 2006.

39. Murena, F.; Prati, M.V. Spatial variability of fine particle number concentration in an urban area. In Proceedings of the Seventh International Conference on Environmental Management, Engineering, Planning and Economics (CEMEPE 2019) and SECOTOX Conference, Mykonos Island, Greece, 19-24 May 2019.

40. Murena, F.; Vorraro, F. Vertical gradients of Benzene in a narrow street canyon in urban area of Naples. Atmos. Environ. 2003, 37, 4853-4859. [CrossRef]

41. Murena, F.; Favale, G. Continuous monitoring of carbon monoxide in a deep street canyon. Atmos. Environ. 2007, 41, 2620-2629. [CrossRef]

42. Murena, F. Sustainable development of the old center of Naples: The impact of vehicular traffic and catering activities on the air quality. Atmosphere 2021, 11, 938. [CrossRef]

43. Cattani, G.; Cusano, M.; Di Menno di Bucchianico, A.; Fioravanti, G.; Gaeta, A.; Gaddi, R.; Gandolfo, G.; Lena, F.; Leone, G. Qualità dell'Ambiente Urbano-XV Rapporto (2019) 5. Inquinamento Dell'aria E Cambiamenti Climatici; Report SNPA 13/2020; Istituto superiore per la protezione e la ricerca ambientale: Rome, Italy, 2019.

44. Fattoruso, G.; Nocerino, M.; Toscano, D.; Pariota, L.; Sorrentino, G.; Manna, V.; De Vito, S.; Cartenì, A.; Fabbricino, M.; Di Francia, G. Site Suitability Analysis for Low Cost Sensor Networks for Urban Spatially Dense Air Pollution Monitoring. Atmosphere 2020, 11, 1215. [CrossRef] 